\title{
Editorial
}

Starting a new journal is a challenging task especially if it is devoted to a real exchange of ideas between East and West. The Journal for East European Management Studies (JEEMS) will contribute towards the development of management knowledge in Central and East European countries as well as to a more sophisticated understanding of new and unique trends, tendencies and problems within these countries.

Here we are! The first issue shows how we would like to develop.

The first article from Dirk Holtbrügge (Dortmund) is about German-Russian joint ventures and gives the result of studies since 1993. It shows, especially, the cultural problems associated with such cooperation. Vincent Edwards (Buckinghamshire) and Peter Lawrence (Loughborough) present a British view on an East German company in its transitional period. Snejina Michailova (Sofia/ Copenhagen) explores the dynamics of the relationships between macro and micro changes in Bulgaria at societal and organizational level with references to the result of a case study in a large Bulgarian enterprises.

The „Forum“ starts with a discussion on research methods. Klaus Lindert (Braunschweig) favours a quantitative, longitudinal studies approach to research on transformation at organizational level, but Jolanta Kulpinska and Krzysztof Konecki (Lódz) support a case studies oriented concept.

In general, short contributions, for example comments on articles, position papers and letters to the editor are welcome here.

„News / Information“ includes short conference reports as well as information about new research and teaching institutions, as well as programmes in and on Central and Eastern Europe. And, finally, John Erpenbeck's column shows the way in which we should deal with the problems in Eastern Europe: with an opening to a unique process where we could all learn a lot ... if we really want to.

Starting a new journal is not an easy thing. A lot of work has had to be done and would have been impossible without the help of colleagues from different places and countries in the East and West. Thanks to them all!

\section{Rainhart Lang}




\title{
Call for papers \\ III. Chemnitz East Forum
}

March 5 - 7, 1997

Technical University Chemnitz-Zwickau

The III. Chemnitz East Forum, chaired by Prof. Dr. Rainhart Lang, is dealing with

\author{
„Managers in the Transformation Process of Eastern Europe“ \\ - Manager careers, old elites/new elites \\ - Values and management attitudes \\ - Leadership styles and work relations \\ - Management development
}

Applications and papers in the field of this subject (max. 2 pages) are welcome. As far as possible participants from Eastern European countries will get their expenses for travel and accommodation refunded.

For further information please contact: $\mathrm{Mr}$ Thomas Steger, Technische Universität Chemnitz-Zwickau, Fakultät für Wirtschaftswissenschaften, Reichenhainer Str. 39, D - 09107 Chemnitz, tel. +49-371-5314159, fax +49371-5313987,E-mail t.steger@wirtschaft.tu-chemnitz.de

\section{Call for papers \\ III. Chemnitzer Ostforum}

5.-7. März 1997

Technische Universität Chemnitz-Zwickau

Das III. Chemnitzer Ostforum steht unter der Leitung von Prof. Dr. Rainhart Lang und widmet sich dem Thema

„Führungskräfte im osteuropäischen Transformationsprozeß“

- Manager-Karrieren, alte Eliten/neue Eliten

- Wertorientierungen und Führungsverständnis

- Führungsstil und Mitarbeiterbeziehungen

- Führungskräfte-Qualifizierung

Voranmeldungen sowie Kurzfassungen/Abstracts (max. 2 Seiten) sind erbeten an die untenstehende Adresse. Teilnehmern aus osteuropäischen Staaten werden die Reise- und Aufenthaltskosten im Rahmen der Möglichkeiten erstattet.

Weitere Informationen erteilt: Herr Thomas Steger, Technische Universität Chemnitz-Zwickau, Fakultät für Wirtschaftswissenschaften, Reichenhainer Str. 39, D - 09107 Chemnitz, Tel. +49-371-5314159, Fax +49-371-5313987, E-mail t.steger@wirtschaft.tu-chemnitz.de 